\title{
Social Skills of Students from Educational Sciences: Validity, Reliability, and Percentiles for Evaluation
}

\author{
Emilio Rodriguez-Macayo ${ }^{1}$, Rubén Vidal-Espinoza ${ }^{1}$, Rossana Gómez-Campos ${ }^{2} \&$ Marco Cossio-Bolaños $^{3}$ \\ ${ }^{1}$ Universidad Católica Silva Henriquez, Santiago, Chile \\ ${ }^{2}$ Departamento de Diversidad e Inclusividad Educativa. Universidad Católica del Maule, Talca, Chile \\ ${ }^{3}$ Departamento de Ciencias de la Actividad Física, Universidad Católica del Maule, Talca, Chile \\ Correspondence: Marco Cossio Bolaños. Universidad Católica del Maule. Av San Miguel 3605, s/n. Talca, Chile.
}

Received: December 18, 2020

Accepted: February 11, 2021

Online Published: February 19, 2021

doi:10.5430/ijhe.v10n3p259

URL: https://doi.org/10.5430/ijhe.v10n3p259

\begin{abstract}
The development of social skills (SS) at various stages of life provides the basis for social and academic success throughout life. This cross-sectional study validates and verifies the reliability of the SS checklist proposed by Goldstein et al 1983. The checklist was administered, which is composed of 6 dimensions and 50 SS questions. 671 students between 18 and 25 years of age, belonging to eight professional programs in the area of Educational Sciences, participated. The results showed that five factors explained $41.4 \%$ of the variance of the instrument. The Kaiser-Meyer-Olkin KMO measure of 0.906 and Bartlett's test of sphericity were highly significant $\left(\mathrm{X}^{2}=11020.251\right.$, $\mathrm{gl}=1225$ ). The factor loadings of the 6 dimensions and the 50 questions ranged between 0.42 and 0.72 . The reliability achieved by Cronbach's alpha was $r=0.92$. The proposal of percentiles will allow classifying low, moderate and high levels of SS, providing information that can be used not only by students, but also for professionals working in higher education. Consequently, it highlights the importance of developing SS not only at home, but also at school and university, since they need to be stimulated at every stage of life to achieve the proposed objectives.
\end{abstract}

Keywords: social skills, validity, percentiles, university students

\section{Introduction}

In general, Social Skills (SS) are defined as learned behaviors and socially acceptable (Patrick, 2008). They allow the individual to interact with others and avoid unacceptable behaviors that may result in negative social interactions with others (Olaz, 2012). Generally, researchers have suggested that SS developed at diverse stages of life provide the fundamental basis for social and academic success throughout the life cycle (Arnold, Kupersmidt, Voegler-Lee, \& Marshall, 2012; Del Giudice, 2014; Halle, Hair, Wandner, \& Chien, 2012). Therefore, improving SS is quite important for people's personal and professional development, as improving these skills helps people to become better builders of human relationships (Gökel \& Dagli, 2017).

Historically, treatments and interventions have been used to improve specific training attitudes of individuals. Communication skills and adaptation in various social contexts have been crucial for improving self-awareness, self-efficacy, and self-confidence (Bellack \& Hersen, 1979; Yalom \& Leszcz, 2005). In this context, SS have been included in higher education as a discipline to study to generate controlled social interaction scenarios. Thus, it is possible to lay the foundations of a repertoire of SS appropriate for professional needs (Rosa, Navarro-Segura, \& Lopez, 2014). As a result, a number of studies have demonstrated the success of training SS to diverse populations from infancy (Bueno, Durán Segura, \& Garrido, 2013) to adolescence (Fernández \& Frayle, 2008; Rosa et al., 2014). This shows that SS in addition to successful personal and social relationships as well as professional success and competence may be improved and/or optimized through training (Monjas-Casares, 2004). Therefore, its evaluation and diagnosis are relevant from early ages. At advanced ages, it is possible to observe the benefits in diverse environments such as labor, educational, clinical, and psychological (Viscarro, 1994).

In the context of university higher education, the assessment of SS is relevant to know the competent behavior of future professionals. The transition between university and professional life implies high levels of demand for a young person, in an environment where it is necessary to employ theoretical knowledge as well as an elaborated repertoire of interpersonal skills to succeed in the current workplace (Morán, Olaz, \& Del Prette, 2015). 
Consequently, it is important to highlight that most international (Leal-Costa, Luján-Cebrián, Gascón-García, Ferrer-Villalonga, \& Van-der Hofstadt Román, 2010; Pedraza, Socarrás, Fragozo, \& Vergara, 2014; Rosa et al., 2014; Ternera, \& De Biava., 2009) and national (Abarca \& Hidalgo, 1989; Miranda-Zapata, Riquelme-Mella, Cifuentes-Cid, \& Riquelme-Bravo, 2014; Morán, García, \& Hormazábal, 2018) have relied on developing psychometric studies using factor analysis explorations, however, to our knowledge, no study has been identified that has used the SS checklist of Goldstein et al. (1983), and they do not have reference values to categorize and classify the levels of SS according to age range and sex.

Therefore, the hypothesis for this study was that the SS checklist proposed by Goldstein consisting of six dimensions (basic and advanced skills, skills related to emotions and aggression, skills for dealing with stress, and for planning) could be valid and reliable for use with university students in the area of Educational Sciences. Based on this information, it is possible to develop percentiles in order to classify the levels of SS of these university students. This information may help to develop an intervention program for students in educational sciences. The intent of this research was to improve students' academic, employment, and SS for the future. Thus, the objectives were the following: a) validate the scale for social skills, b) verify the reliability of the scale for social skills, and c) propose percentiles for the levels of social skills for the scale for students in educational sciences at a university in Santiago, Chile.

\section{Method}

\subsection{Type of Study and Sample}

A descriptive cross-sectional study was carried out. Sample selection was non-probabilistic (non-random or chance) with 671 university students (128 males and 556 females) studied. Ages ranged between 18 and 25 years old. Students from 8 professional programs in educational sciences from a university in Santiago, Chile were included in the study: Pedagogy in Special Education, Pre-school Education, Technical Education Pedagogy, Art Education Pedagogy, Mathematics and Computer Science Pedagogy, Elementary Education Pedagogy, Physical Education Pedagogy, and English Pedagogy.

Students included in the study were those signing the informed consent form and attending the day the SS checklist was administered. Students excluded were those not signing the consent form and students 26 years of age or older (6 students). The research was carried out according to the Declaration of Helsinki and the Ethics Committee from the USE.

\subsection{Techniques and Procedures}

The social skills variable was measured by means of the survey technique. The instrument used was the checklist proposed by Goldstein et al. (1983). This checklist consists of 6 dimensions and a total of 50 questions: I) basic social skills (questions 1-8), II) advanced social skills (questions 9-14), III) skills related to emotions (questions 15-21), IV) skills related to aggression (questions 22-30), V) skills for dealing with stress (questions 31-42), and VI) skills for planning (questions 43-50). Four alternate questions were also developed: a) It happens to me very few times, b) it happens to me a lot of times, c) it happens to me sometimes, and d) It happens to me many times. Demographic variables were also collected: age, sex, how entered the university, marital status, and type of school.

The survey instrument was administered at the facilities of the Faculty of Educational Sciences from 8:30 a.m. to 1300 p.m. Data collection was carried out from April to May 2018. The standard traditional method (pencil and paper) was used for students to answer the checklist. Four trained examiners with significant experience in administering questionnaires were in charge of all procedures (one for each classroom). The examiners described and explained the procedures to the students answering the checklist expected to take between 15 to 20 minutes to complete.

\subsection{Validity and Reliability}

The social skills instrument was validated by means of the construct validity method. Exploratory factor analysis was carried out. Once the rotation of the results had been completed, they were converted into six factors or dimensions. Reliability was determined by means of internal consistency (Cronbach's Alpha).

\subsection{Statistical Analysis}

The normality of the data was verified by means of the Kolmogorov-Smirnov test. Afterwards, the data was analyzed through descriptive statistics (frequencies, percentages, averages (X), standard deviation, and range). Comparisons between both sexes were determined by means of the t-test for independent samples, and the differences between prevalences were calculated using $\mathrm{X}^{2}$. The main component extraction technique, Varimax rotation, 
Kaiser-Meier-Olkin (KMO), the same values (Eigen), and percentage of variance were used to validate the procedure. For reliability, Cronbach's alpha (r) was used. Goodness of fit was used to determine the soundness of the model. Its KMO value needed to be $\geq 0.90$. The LMS method proposed by Cole, Bellizzi, Flegal, \& Dietz (2000) was used to determine the percentiles. Smoothed curves were created: $\mathrm{L}(\mathrm{t})$ Box-Cox Power, $\mathrm{M}(\mathrm{t})$ median, and $\mathrm{S}(\mathrm{t})$ coefficient of variation to generate the percentiles ( $\mathrm{p} 5, \mathrm{p} 10, \mathrm{p} 15, \mathrm{p} 50, \mathrm{p} 85$, $\mathrm{p} 90$, and $\mathrm{p} 95$ ). The cut-off points included the following: a) high levels of social skills $\geq p 85$, b) moderate levels from $\mathrm{p} 15$ to $\mathrm{p} 85$, and c) low levels of social skills $\mathrm{p}<15$. Initially, the results were processed and analyzed with Excel sheets and afterwards with SPSS 18.0. For all cases, $\mathrm{p}<0.05$ was adopted.

\section{Results}

The variables studied for this research are portrayed in Table 1. No significant differences occurred in the six dimensions when they were compared by sex. Furthermore, when the percentages were compared by marital status and income, no differences occurred in prevalence ( $p>0.05$ ). However, when compared by type of school, differences occurred in both sexes, predominantly more females and students coming from municipal/public schools.

Table 1. Characteristics of the sample studied.

\begin{tabular}{|c|c|c|c|c|c|c|}
\hline \multirow{2}{*}{ Social Skills } & \multicolumn{2}{|c|}{ Males } & \multicolumn{2}{|c|}{ Females } & \multicolumn{2}{|c|}{ Both } \\
\hline & $\mathbf{X}$ & SD & $\mathbf{X}$ & SD & $\mathbf{X}$ & SD \\
\hline S. Basic & 31.2 & 4.1 & 32.7 & 3.5 & 32.4 & 3.6 \\
\hline S. Advanced & 23.5 & 2.8 & 24 & 2.8 & 23.9 & 2.8 \\
\hline S. Related to emotions & 25.9 & 4 & 27.4 & 3.6 & 27.1 & 3.7 \\
\hline S. Related to aggression & 37.3 & 4.3 & 37.8 & 4.2 & 37.7 & 4.2 \\
\hline S. for dealing with stress & 46.9 & 6.5 & 48.1 & 6 & 47.9 & 6.1 \\
\hline S. for planning & 32.3 & 4.4 & 33.7 & 4.1 & 33.5 & 4.2 \\
\hline Marital Status & $\mathbf{N}$ & $\%$ & $\mathbf{N}$ & $\%$ & $\mathbf{n}$ & $\%$ \\
\hline Single & 101 & 95 & 487 & 96 & 588 & 96 \\
\hline Narried & 4 & 4 & 9 & 2 & 13 & 2 \\
\hline Divorced & 0 & 0 & 2 & 0 & 2 & 0 \\
\hline Cohabitating & 1 & 1 & 9 & 2 & 10 & 2 \\
\hline \multicolumn{7}{|l|}{ Way of entering university } \\
\hline PSU & 93 & 88 & 454 & 90 & 547 & 89 \\
\hline Equivalency & 1 & 1 & 7 & 1 & 8 & 1 \\
\hline High school & 3 & 3 & 8 & 2 & 11 & 2 \\
\hline PACE & 3 & 3 & 30 & 6 & 33 & 5 \\
\hline Other & 8 & 8 & 11 & 2 & 19 & 3 \\
\hline \multicolumn{7}{|l|}{ Type of School } \\
\hline Municipal/public school & 83 & 78 & 300 & 59 & 383 & 63 \\
\hline Subsidized school & 25 & 24 & 201 & 40 & 226 & 37 \\
\hline Private school & 108 & 102 & 5 & 1 & 113 & 18 \\
\hline
\end{tabular}

Legend: X: Average, SD: Standard deviation, PSU: University entrance selection exam, PACE: Support and Financial Aid Program for Higher Education, S: Skills, Marital status: $X^{2}=2.0, g l=3 ; p=0.5723$, Way of entering: $\mathrm{X}^{2}=4.8, \mathrm{gl}=4 ; \mathrm{p}=0.3081$, Type of school: $\mathrm{X}^{2}=7.9, \mathrm{gl}=2 ; \mathrm{p}<0.001$

The descriptive statistics by question and dimension as well as the values for the factor analysis by main components by means of Varimax rotation are illustrated in Table 2. Five factors explained 41.4 percent of the variance of the instrument. In the adequacy model, the Kaiser-Meyer-Olkin KMO measure was from 0.906. Bartlett's sphericity test was highly significant $\left(\mathrm{X}^{2}=11020.251, \mathrm{gl}=1225, \mathrm{p}<0.001\right)$. Factorial loads in the six dimensions and the 50 questions oscillated between 0.42 and 0.72 . In general, the reliability showed Cronbach's Alpha of ( $\mathrm{r}=0.92)$. 
Table 2. Average values, SD, model of six first-order factors, and Cronbach's Alpha for the social skills questionnaire.

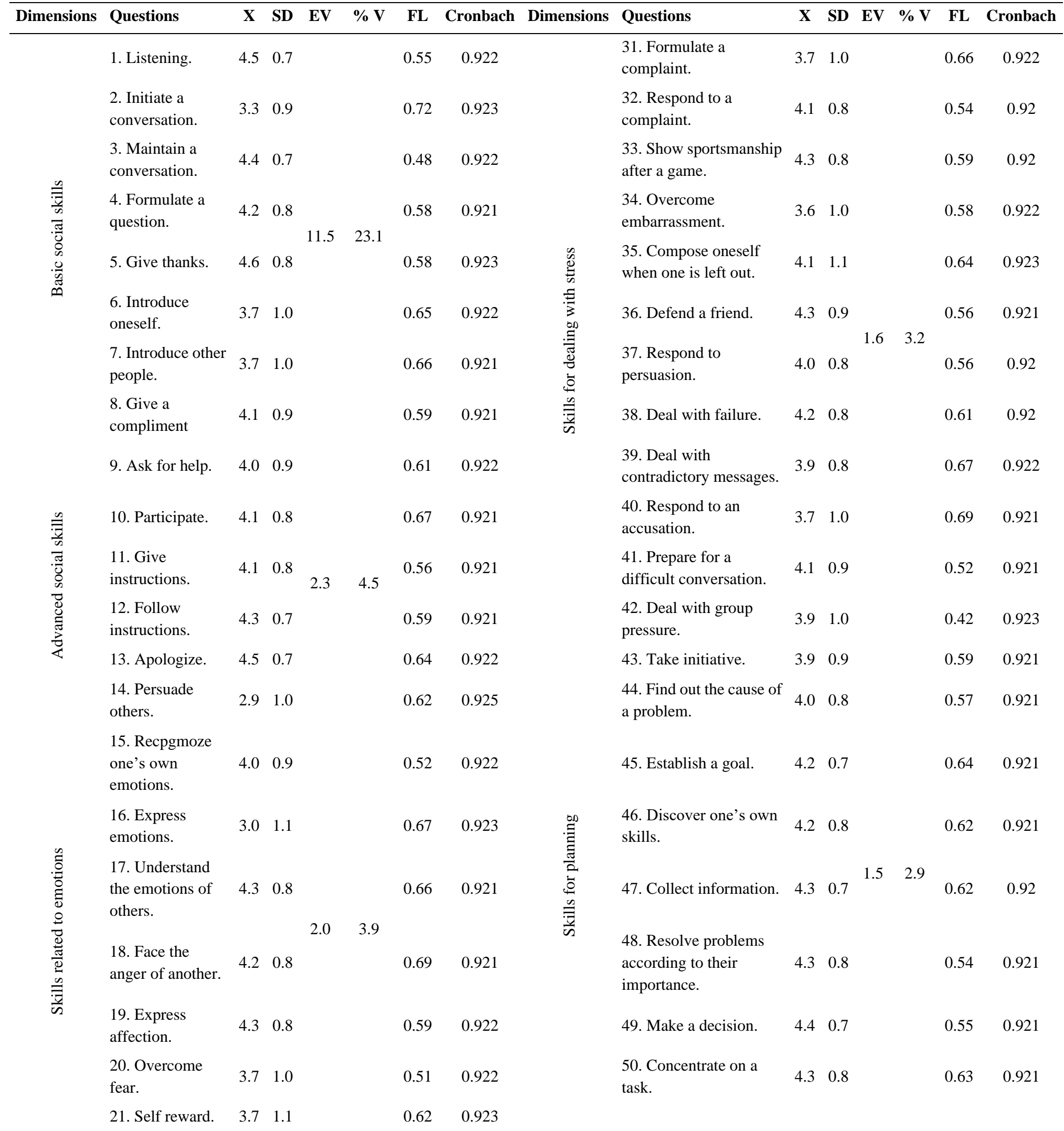




\begin{tabular}{|c|c|c|c|c|c|c|}
\hline $\begin{array}{l}\text { 22. Ask for } \\
\text { permission. }\end{array}$ & 4.5 & 0.7 & & & 0.57 & 0.921 \\
\hline $\begin{array}{l}\text { 23. Share } \\
\text { something. }\end{array}$ & 4.2 & 0.8 & & & 0.59 & 0.921 \\
\hline 24. Help others. & 4.6 & 0.7 & & & 0.55 & 0.921 \\
\hline 25. Negotiate. & 3.9 & 0.8 & & & 0.57 & 0.921 \\
\hline $\begin{array}{l}\text { 26. Begin self } \\
\text { control. }\end{array}$ & 3.9 & 0.9 & & & 0.64 & 0.922 \\
\hline $\begin{array}{l}27 . \text { Defend one's } \\
\text { own rights. }\end{array}$ & 4.3 & 0.8 & 1.9 & 3.8 & 0.65 & 0.921 \\
\hline $\begin{array}{l}28 . \text { Respond to } \\
\text { jokes. }\end{array}$ & 4.1 & 0.9 & & & 0.64 & 0.923 \\
\hline $\begin{array}{l}\text { 29. Avoid } \\
\text { problems with } \\
\text { others. }\end{array}$ & 4.2 & 0.9 & & & 0.6 & 0.922 \\
\hline $\begin{array}{l}\text { 30. Do not ge } \\
\text { tinto fights }\end{array}$ & 4.3 & 0.8 & & & 0.64 & 0.921 \\
\hline
\end{tabular}

Legend: X: Average, SD: Standard Deviation, EV: Eigen values, \%V: Percent of Variance, FL: Factor load.

Table 3. Percentile values of social skills for students from educational sciences.

\begin{tabular}{|c|c|c|c|c|c|c|c|c|c|c|c|c|c|c|c|c|}
\hline Age (years) & $\mathrm{L}$ & $\mathrm{M}$ & $\mathrm{S}$ & P5 & $\mathrm{P} 15$ & P50 & P85 & P95 & $\mathrm{L}$ & $\mathrm{M}$ & $\mathrm{S}$ & P5 & P15 & $\mathrm{P} 50$ & P85 & P95 \\
\hline \multicolumn{17}{|c|}{ Basic skills } \\
\hline $17-19$ & 2.26 & 31.41 & 0.13 & 24 & 27 & 31 & 35 & 37 & 1.62 & 32.86 & 0.10 & 27 & 29 & 33 & 36 & 38 \\
\hline $20-22$ & -1.33 & 31.17 & 0.12 & 26 & 28 & 31 & 36 & 39 & 2.87 & 32.91 & 0.10 & 26 & 29 & 33 & 36 & 38 \\
\hline $23-25$ & -3.21 & 30.45 & 0.05 & 28 & 29 & 30 & 32 & 34 & 1.66 & 32.36 & 0.12 & 25 & 28 & 32 & 36 & 38 \\
\hline \multicolumn{17}{|c|}{ Advanced skills } \\
\hline $17-19$ & 2.84 & 23.20 & 0.11 & 18 & 20 & 23 & 26 & 27 & 1.51 & 24.04 & 0.12 & 19 & 21 & 24 & 27 & 28 \\
\hline $20-22$ & -0.31 & 24.38 & 0.08 & 22 & 23 & 24 & 27 & 28 & 1.63 & 24.25 & 0.11 & 20 & 21 & 24 & 27 & 29 \\
\hline $23-25$ & 0.39 & 25.33 & 0.07 & 22 & 23 & 25 & 27 & 29 & 1.75 & 23.62 & 0.11 & 19 & 21 & 24 & 26 & 28 \\
\hline \multicolumn{17}{|c|}{ Skills related to emotions } \\
\hline $17-19$ & 1.12 & 26.18 & 0.14 & 20 & 22 & 26 & 30 & 32 & 1.07 & 27.46 & 0.13 & 22 & 24 & 28 & 31 & 33 \\
\hline $20-22$ & 1.85 & 26.00 & 0.18 & 17 & 21 & 26 & 30 & 33 & 2.16 & 27.90 & 0.13 & 21 & 24 & 28 & 32 & 33 \\
\hline $23-25$ & 1.22 & 24.05 & 0.12 & 19 & 21 & 24 & 27 & 29 & 1.03 & 25.81 & 0.14 & 20 & 22 & 26 & 30 & 32 \\
\hline \multicolumn{17}{|c|}{ Skills related to agression } \\
\hline $17-19$ & 2.70 & 37.45 & 0.11 & 30 & 33 & 38 & 41 & 43 & 3.12 & 38.36 & 0.10 & 31 & 34 & 38 & 42 & 44 \\
\hline $20-22$ & 1.40 & 37.90 & 0.12 & 30 & 33 & 38 & 43 & 45 & 3.05 & 38.30 & 0.11 & 30 & 33 & 38 & 42 & 44 \\
\hline $23-25$ & 8.36 & 39.19 & 0.06 & 32 & 36 & 39 & 41 & 42 & 1.53 & 37.02 & 0.13 & 29 & 32 & 37 & 42 & 45 \\
\hline \multicolumn{17}{|c|}{ Skills for dealing with stress } \\
\hline $17-19$ & 1.72 & 46.73 & 0.14 & 35 & 40 & 47 & 53 & 57 & 1.78 & 48.29 & 0.12 & 38 & 42 & 48 & 54 & 57 \\
\hline $20-22$ & -1.49 & 46.22 & 0.12 & 39 & 41 & 46 & 53 & 58 & 3.49 & 49.22 & 0.11 & 38 & 43 & 49 & 54 & 56 \\
\hline $23-25$ & 8.46 & 52.16 & 0.06 & 42 & 48 & 52 & 55 & 56 & 2.34 & 48.36 & 0.11 & 39 & 43 & 48 & 53 & 56 \\
\hline \multicolumn{17}{|c|}{ Organizational Skills } \\
\hline $17-19$ & 4.37 & 33.10 & 0.11 & 22 & 28 & 33 & 36 & 38 & 2.95 & 34.16 & 0.11 & 26 & 30 & 34 & 38 & 40 \\
\hline $20-22$ & -0.32 & 33.10 & 0.09 & 29 & 30 & 33 & 36 & 39 & 3.69 & 34.60 & 0.10 & 27 & 30 & 35 & 38 & 39 \\
\hline
\end{tabular}




\begin{tabular}{lcccccccccccccccc}
$23-25$ & 0.75 & 33.10 & 0.11 & 27 & 29 & 33 & 37 & 39 & 3.26 & 33.19 & 0.10 & 26 & 29 & 33 & 36 & 38 \\
& \multicolumn{10}{c}{ Total of Scocial Skills Scale } \\
$17-19$ & 2.27 & 196.91 & 0.10 & 159 & 174 & 197 & 217 & 228 & 2.38 & 204.94 & 0.09 & 171 & 185 & 205 & 223 & 232 \\
$20-22$ & 0.19 & 199.25 & 0.10 & 169 & 180 & 199 & 220 & 233 & 3.74 & 206.89 & 0.09 & 169 & 186 & 207 & 223 & 232 \\
$23-25$ & 5.29 & 204.12 & 0.07 & 174 & 188 & 204 & 216 & 222 & 2.33 & 200.46 & 0.10 & 164 & 178 & 200 & 220 & 230
\end{tabular}

Legend: P: Percentile, L: Box-Cox Power, M: Mean, and S: Coefficient of variation.

\section{Discussion}

The purpose of the first objective of this study was to validate the social skills scale for students of Educational Sciences of a university in Santiago, Chile. Exploratory factorial analysis was carried out. The model reflected the six factors proposed in the original scale.

This model was adjusted for the sample used for this study. The saturation values for the 50 questions were higher than 0.42 and the Eigen values <1.0. These results are similar to those of other studies. In addition, the adjusted indices are relatively similar to other studies where construct validity has been used with social skills scales for other university populations (Miranda-Zapata et al., 2014; Morán et al., 2018).

The results confirmed the hypothesis proposed using Goldstein's et al. (1983) scale for the 6 dimensions and 50 questions. These were validated using exploratory factorial analysis with students from educational sciences. This process guarantees that the covariance values may present similar behaviors between the estimated and the expected results. Consequently, the results may be duplicated in the subjects studied (Tornimbeni, Pérez, Olaz, de Kohan, Fernández, \& Cupani, 2008).

As a result, the researchers need to use in their internal structures robust techniques such as exploratory factorial analysis. This would guarantee psychometric properties of their instruments (Morán \& Olaz, 2014).

The second objective of this study was to verify the reliability of the social skills scales. In general, the reliability involves three classic procedures, such as split halves, test re-test, and internal consistency. This last procedure refers to the consistency of each person's score taking the test (Cappello, Aguirre, Castro, Cervantes, Infante, \& Marín, 2004). The results obtained from this research show an adequate proportion for all of the items. This guarantees a higher correlation between the subjects responding and, a consequent, consistency between the questions.

Cronbach's coefficient showed an alpha of 0.90 for each question and for the totality of the instrument. These findings are consistent with studies that have used the same reliability technique in SS scales with similar characteristics of this present study (Morán et al., 2018; Bandeira, Del Prette, Del Prette, \& Magalhães, 2009; Miranda-Zapata et al., 2014) and with other scales that have similar reliability purposes (Pulido-Acosta \& Herrera-Clavero, 2017), despite the fact that these last studies have shown inferior values $(\alpha 0.70)$ compared to the present research (Pulido-Acosta \& Herrera-Clavero, 2017).

In relation to the proposed scales, the third objective proposed for this study was to develop percentiles to evaluate the social skills of students from educational sciences. Upon confirmation of the validity and reliability of this proposed scale, for this research, percentiles were developed to assess social skills based on age and sex. These references may be used to help assess and analyze the ongoing progress of a particular variable (Nichols, Meyers, \& Burling, 2009) and to analyze the formation process of students (Black \& Wiliam, 2009). However, generally, the cut-off points based on percentiles are used to facilitate assessing the distance between what has been reached and what the reference indicates as a cut-off point. It is also used an instrument that serves to record students' history of learning and/or progress of learning (Seo \& Taherbhai, 2015). In this specific case for the present study, its uses are to monitor and classify the social skills of students in educational sciences.

In this sense, for this study, the cut-off points for the social skills have been identified as low levels <p15, p15-p85 as moderate levels, and $\geq \mathrm{p} 85$ as high levels of social skills. The information provided here may be used not only by students but also for professionals working in higher education making it possible with this instrument to identify the levels of social skills of students from educational sciences at predetermined times.

For example, some research studies have shown that students with low social skill levels demonstrate eating disorders (Gismero-Gonzalez, 2001) and frustration with the university program (dos Santos Mello \& Benevides Soares, 2014). At the same time, high levels of social skills have a positive effect on the social and family climates (Garcia, 2005), and including, greater social competency may serve as a protection factor decreasing stress levels and improving quality of life (Bandeira, 2002). Thus, social skills need to be constantly developed, not only at home, but 
also at the school and university since they need to be stimulated at each stage of life to achieve the proposed objectives.

Consequently, self-reporting measures are a significant resource among the various social skills assessment procedures (Eceiza, Arrieta, \& Goñi, 2008). This may help prevent future problematic behaviors that tend to occur in school, such as student dropout, stress, violent behavior, and criminal activities (Shirilla, 2009).

In general, young people with a sufficient set of basic, advanced, emotion-related, aggression-related, as well as stress coping and planning SS may present better opportunities in future work, as they depend on the quality of social interactions and age throughout life (Zutiao, Costa, \& Lessa, 2018), as they are determinant aspects that should be considered, not only in students of educational sciences, but also in other professional programs.

Future studies should be interested in other validation techniques, as well as extending to other professional programs, including, the results obtained in this study can serve as a baseline for comparisons in the coming years and verify positive and/or negative trends in SS.

Some limitations need to be acknowledged about this research. For example, the sample selection was non-probabilistic. Therefore, generalizability is limited to only the students researched in this study. The use and application of the results need to be analyzed with caution. Despite the above, this study presents some strengths, given that it is the first time that the Goldstein instrument has been validated in Chile and can be used by educational science professionals to identify young people with lower levels of SS and to evaluate the effectiveness of intervention programs.

\section{Conclusions}

The conclusion drawn from this research is that the scale applied in this study is valid and reliable. It may be used to assess social skills. Furthermore, the proposed percentiles may help evaluate, classify, and monitor students from educational sciences. This information may be relevant for detecting difficulties related to social skills that are basic, advanced, related to emotions, aggression, stress, and planning. The results may also be used to develop intervention programs during the formation stage for students at university. The calculations for the scale may be carried out in real time using the following link: http://www.reidebihu.net/ninos_adolescentes.php

\section{References}

Abarca, N., \& Hidalgo, C. G. (1989). Evaluación psicométrica de habilidades sociales en jóvenes universitarios Chilenos. Revista Análisis del comportamiento, 4, 51-62.

Arnold, D. H., Kupersmidt, J. B., Voegler-Lee, M. E., \& Marshall, N. A. (2012). The association between preschool children's social functioning and their emergent academic skills. Early Childhood Research Quarterly, 27(3), 376-386. https://doi.org/10.1016/j.ecresq.2011.12.009

Bandeira, M. (2002). Escala de Avaliação da Competência Social de Pacientes Psiquiátricos através de Desempenho de Papéis: EACS. Avaliação Psicológica, 1(2), 159-171.

Bandeira, M., Del Prette, Z. A. P., Del Prette, A., \& Magalhães, T. (2009). Validação das escalas de habilidades sociais, comportamentos problemáticos e competência acadêmica (SSRS-BR) para o ensino fundamental. Psicologia: teoria e pesquisa, 25(2), 271-282. https://doi.org/10.1590/S0102-37722009000200016

Bellack, A S. (1979). Behavioral Assessment of Social Skills. In A. S. Bellack \& M. Hersen (Eds.), Research and Practice in Social Skills Training (pp. 75-104). Boston, MA: Springer US. https://doi.org/10.1007/978-1-4899-2192-5_3

Black, P., \& Wiliam, D. (2009). Developing the theory of formative assessment. Educational Assessment, Evaluation and Accountability (Formerly: Journal of Personnel Evaluation in Education), 21(1), 5. https://doi.org/10.1007/s11092-008-9068-5

Bueno Moreno, M. R., Durán Segura, M., \& Garrido Torres, M. Á. (2013). Entrenamiento en habilidades sociales en estudiantes universitarios de Magisterio de la especialidad de Educación Primaria: un estudio preliminar. Apuntes de Psicología, 31(1), 85-91.

Cappello, H., Aguirre, M., Castro, R., Cervantes, R., Infante, J., \& Marín, R. (2004). Estudio del análisis de la consistencia interna y la validez de construcción de una prueba en el programa de enseñanza vivencial de las ciencias. Revista Internacional de Ciencias Sociales y Humanidades, SOCIOTAM, XIV(2), 47-72. 
Cole, T. J., Bellizzi, M. C., Flegal, K. M., \& Dietz, W. H. (2000). Establishing a standard definition for child overweight and obesity worldwide: international survey. BMJ, 320(7244), 1240. https://doi.org/10.1136/bmj.320.7244.1240

Del Giudice, M. (2018). Middle Childhood: An Evolutionary-Developmental Synthesis. In N. Halfon, C. B. Forrest, R. M. Lerner, \& E. M. Faustman (Eds.), Handbook of Life Course Health Development (pp. 95-107). Cham: Springer International Publishing. https://doi.org/10.1007/978-3-319-47143-3_5

dos Santos Mello, T., \& Benevides Soares, A. (2014). Habilidades Sociais e Frustração em Estudantes Universitários De Medicina. Ciencias Psicológicas, 8(2), 163-172.

Eceiza, M., Arrieta, M., \& Goñi, A. (2008). Habilidades Sociales y Contextos de la Conducta Social. Revista de Psicodidáctica, 13(1), 11-26.

Fernández, N. G., \& Fraile, C. L. (2008). Evaluación de las competencias sociales en estudiantes de enfermería. Bordón. Revista de pedagogía, 60(2), 91-106.

García, C. R. (2005). Habilidades sociales, clima social familiar y rendimiento académico en estudiantes universitarios. Liberabit, 11(11), 63-74. http://pepsic.bvsalud.org/scielo.php?script=sci_arttext\&pid=S172948272005000100008

Gismero-González, E. (2001). Evaluación del autoconcepto, la satisfacción con el propio cuerpo y las habilidades sociales en la anorexia y bulimia nerviosas. Clínica y Salud, 12(3), 289-304.

Gökel, O, \& Dağlı G. (2017). Effects of Social Skill Training Program on Social Skills of Young People. EURASIA Journal of Mathematics, Science and Technology Education, 13(11), 7365-7373. https://doi.org/10.12973/ejmste/79615

Goldstein, A. P., Sprafkin, R. P., Gershaw, \& Klein, P. (1983). Structured Learning: A Psychoeducational Approach for Teaching Social Competencies. Behavioral Disorders, 8, 161-170. https://doi.org/10.1177/019874298300800307

Halle, T. G., Hair, E. C., Wandner, L. D., \& Chien, N. C. (2012). Profiles of school readiness among four-year-old Head Start children. Early Childhood Research Quarterly, 27(4), 613-626. https://doi.org/10.1016/j.ecresq.2012.04.001

Leal-Costa, C., Luján-Cebrián, I., Gascón-García, J., Ferrer-Villalonga, L., \& Van-der Hofstadt Román, C. J. (2010). Habilidades sociales en los profesionales de urgencias y cuidados críticos de un hospital público comarcal. Enfermería Intensiva, 21(4), 136-141. https://doi.org/10.1016/j.enfi.2010.05.001

Miranda-Zapata, E., Riquelme-Mella, E., Cifuentes-Cid, H., \& Riquelme-Bravo, P. (2014). Análisis factorial confirmatorio de la Escala de habilidades sociales en universitarios chilenos. Revista Latinoamericana de Psicología, 46(2), 73-82. https://doi.org/10.1016/S0120-0534(14)70010-X

Monjas-Casares, M. I. (2004). Programa de enseñanza de habilidades de interacción social (PEHIS) para niños y niñas en edad escolar. Madrid, Cepe.

Morán, V. E., García, F. E., \& Hormazábal, P. (2018). Validación Transcultural del Cuestionario de Habilidades Sociales para Universitarios en Estudiantes Chilenos y Argentinos (CHS-U). Revista iberoamericana de diagnóstico y evaluación psicológica, 2(47), 111-123. https://doi.org/10.21865/RIDEP47.2.08

Morán, V., Olaz, F., \& Del Prette, Z. (2015). Social Skills Questionnaire for Argentinean College Students (SSQ-U) Development and validation. The Spanish Journal of Psychology. 18, e95, 1-11. https://doi.org/10.1017/sjp.2015.92

Morán, V., \& Olaz, F. (2014). Instrumentos de evaluación de habilidades sociales en América Latina: un análisis bibliométrico. Revista de Psicología, 23(1), 93-105. https://doi.org/10.5354/0719-0581.2014.32877

Nichols, P. D., Meyers, J. L., \& Burling, K. S. (2009). A Framework for Evaluating and Planning Assessments Intended to Improve Student Achievement. Educational Measurement: Issues and Practice, 28(3), 14-23. https://doi.org/10.1111/j.1745-3992.2009.00150.x

Olaz, F. O. (2012). Escala de autoeficacia social para universitarios (EAS-U) Estudios Psicométricos y Bases Conceptuales.

Patrick, N. J. (2008). Social skills for teenagers and adults with sperger Syndrome: London and Philadelphia: Jessica Kingsley Publishers. 
Pedraza, L., Socarrás, X., Fragozo, A., \& Vergara, M. (2014). Caracterización de las habilidades sociales en estudiante de psicología de una universidad pública del Distrito de Santa Marta. Tesis Psicológica, 9(2), 190-201.

Pulido-Acosta, F. P., \& Herrera-Clavero, F. (2017). Validación inicial de un instrumento en construcción para evaluar la Inteligencia Emocional, como conjunto de habilidades, en una muestra de alumnos de Educación Secundaria. Revista Electrónica Interuniversitaria de Formación del Profesorado, 20(1), 35-47. https://doi.org/10.6018/reifop/20.1.250421

Rosa, G., Navarro-Segura, L., \& López, P. (2014). El Aprendizaje de las Habilidades Sociales en la Universidad: Análisis de una Experiencia Formativa en los Grados de Educación Social y Trabajo Social. Formación universitaria, 7(4), 25-38. https://doi.org/10.4067/S0718-50062014000400004

Seo, D., McGrane, J., \& Taherbhai, H. (2015). The Role of Student Growth Percentiles in Monitoring Learning and Predicting Learning Outcomes. Educational Assessment, 20(2), 151-163. https://doi.org/10.1080/10627197.2015.1028621

Shirilla, P. (2009). Adventure-Based Programming and Social Skill Development in the Lives of Diverse Youth: Perspectives from Two Research Projects. Journal of Experiential Education, 31(3), 410-414. https://doi.org/10.1177/105382590803100310

Ternera, L. A. C., \& De Biava, Y. M. (2009). Habilidades sociales en estudiantes de psicología de una Universidad privada de la Costa Caribe Colombiana. Revista iberoamericana de psicología: ciencia y tecnología, 2(1), $39-52$.

Tornimbeni, S., Pérez, E., Olaz, F., de Kohan, N. C., Fernández, A., \& Cupani, M. (2008). Introducción a la psicometría. Buenos Aires: Paidós.

Yalom, I. D., \& Leszcz, M. (2005). The theory and practice of group psychotherapy, 5th ed. New York: Basic Books.

Zutiao, P., Costa, C., \& Lessa, T. R. (2018). Social skills in undergraduate students with different job readiness experiences. Revista Brasileira de Educação Especial, $24(2), \quad$ 261-276. https://doi.org/10.1590/s1413-65382418000200008

\section{Copyrights}

Copyright for this article is retained by the author(s), with first publication rights granted to the journal.

This is an open-access article distributed under the terms and conditions of the Creative Commons Attribution license (http://creativecommons.org/licenses/by/4.0/). 